apgs@ufv.br

Universidade Federal de Viçosa

Brasil

\title{
Theoretical Approaches to the Fragility of States: Proposal for a Comprehensive Model from Political Legitimacy in Statehood Construct
}

Rosvadoski-da-Silva, Patrícia; Corrêa Gomes, Ricardo; Pinheiro Deboçã, Leonardo

Theoretical Approaches to the Fragility of States: Proposal for a Comprehensive Model from Political Legitimacy in Statehood Construct

Administração Pública e Gestão Social, vol. 13, núm. 3, 2021

Universidade Federal de Viçosa, Brasil

Disponible en: https://www.redalyc.org/articulo.oa?id=351566982001 


\title{
Theoretical Approaches to the Fragility of States: Proposal for a Comprehensive Model from Political Legitimacy in Statehood Construct
}

\author{
Aproximações Teóricas para a Fragilidade dos Estados: Proposta de um modelo compreensivo a partir da \\ Legitimidade Política sob a luz do Statehood \\ Enfoques teóricos sobre la fragilidad de los estados: Propuesta de un modelo integral basado en la Legitimidad \\ Política a la luz del Statehood
}

Patricia Rosvadoski-da-Silva

Universidade Federal de Viçosa - Campus Rio Paranaiba,

Brasil

patricia.rosvadoski@ufv.br

Ricardo Corrêa Gomes

Fundação Getúlio Vargas - FGV/SP, Brasil

ricardo.gomes@fgv.br

Leonardo Pinheiro Deboçã

Universidade Federal de Viçosa - Campus Rio Paranaíba,

Brasil

leonardo.deboca@ufv.br
Redalyc: https://www.redalyc.org/articulo.oa? $\mathrm{id}=351566982001$

Recepción: 10 Febrero 2020

Aprobación: 28 Abril 2020

Publicación: 01 Julio 2021

\section{Abstract:}

Objective of the research: The objective of this research is to broaden the understanding of the statehood phenomenon and its relations with political legitimacy, based on the articulation between theoretical propositions.

Theoretical framework: In addition to a general proposition, the essay presents five other specific propositions, which mainly relate to the concept of State, the concept of fragility and the loss of legitimacy. The statehood construct is then configured in the States' structural characteristics and their permanence in conditions that may successful or not.

Methodology: As a theoretical essay, articulating the literature about fragility of the states and their adjacent variables, and dimensioning the statehood construct in key dimensions, the paper construction was guided by the general proposition: Political Legitimacy, a Statehood constituent, in its relations with regimes and forms of government, and with the trust attributed to political actions, is an intervening factor in the fragility manifested in the States.

Results: The paper resulted in the articulation of some theoretical propositions, expanding the view of the statehood phenomenon and its relations with political legitimacy and leading to a comprehensive model.

Originality: The general proposition of the essay is related to Political Legitimacy, a constituent of the State, in its relations with regimes and forms of government, and with the trust attributed to political action, as a factor involved in the Fragility manifested in the States.

Theoretical and practical contributions: Political legitimacy and State presents promising explanatory possibilities in the face of recent geopolitical changes. The fragility of States is an open and relevant theme, in which this paper contributes to the interaction of new variables and the support of the statehood construct to support new studies on State Fragility.

KEYWORDS: Political Legitimacy, Fragility of States, Theoretic Model, Statehood.

\section{Resumo:}

Objetivo da pesquisa: Ampliar o entendimento sobre o fenômeno statehood e suas relações com a legitimidade política, a partir da articulação entre proposições teóricas.

Enquadramento teórico: Além de uma proposição geral, o ensaio apresenta outras cinco proposições específicas, que relacionam, sobretudo, o conceito de Estado, o conceito de fragilidade e a perda da legitimidade, que é alimentada pela confiança conferida 
no plano interno e externo. Configura-se então o construto statehood nas características estruturais dos Estados e na permanência destes em condições que podem ou não ser bem-sucedidas.

Metodologia: Na forma de ensaio teórico, articulando a literatura de fragilidade dos estados e suas possíveis variáveis e dimensionando o construto statehood em dimensões chaves, a construção do artigo foi norteada na seguinte proposição geral: a Legitimidade Política, constituinte do Statehood, em suas relações com regimes e formas de governo, e com a confiança atribuída às ações políticas, é fator interveniente na fragilidade manifesta nos Estados.

Resultados: $\mathrm{O}$ trabalho resultou na articulação de algumas proposições teóricas ampliando o olhar sobre o fenômeno statehood e suas relações com a legitimidade política e levando para um modelo compreensivo ao final do artigo.

Originalidade: A proposição geral do ensaio está relacionada à Legitimidade Política, constituinte do Estado, em suas relações com regimes e formas de governo, e com a confiança atribuída à ação política, como fator envolvido na fragilidade manifestada nos Estados.

Contribuiçôes teóricas e práticas: Os temas relacionados a legitimidade política e do Estado apresentam possibilidades explicativas promissoras em face das mudanças geopolíticas recentes. A fragilidade dos Estados é um tema aberto e relevante, sentido no qual este artigo contribui para a interação de novas variáveis e o suporte do construto statehood para amparar novos estudos sobre Fragilidade dos Estados.

Palavras-Chave: Fragilidade dos Estados, Legitimidade Política, Statehood. .

\section{ReSUMEN:}

Objetivo de la investigación: Ampliar la comprensión del fenómeno statehood y sus relaciones con la legitimidad política, a partir de la articulación entre proposiciones teóricas.

Marco teórico: Además de una proposición general, el ensayo presenta otras cinco proposiciones específicas, que se relacionan principalmente con el concepto de Estado, el concepto de fragilidad, y con la pérdida de legitimidad, alimentado por la confianza conferida a nivel interno y externo. El constructo statehood se configura entonces en las características estructurales de los Estados y su permanencia en condiciones que pueden o no tener éxito.

Metodología: En forma de ensayo teórico, articulando la literatura sobre la fragilidad estatal y sus posibles variables, y dimensionando el constructo statehood en dimensiones clave, la construcción del artículo se guió por la proposición general: Legitimidad Política, un constituyente del statehood, en sus relaciones con los regímenes y formas de gobierno, y con la confianza atribuida a las acciones políticas, es un factor interviniente en la fragilidad manifestada en los Estados.

Resultados: El trabajo resultó en la articulación de algunas proposiciones teóricas, ampliando la visión sobre el fenómeno statehood y sus relaciones con la legitimidad política y conduciendo a un modelo integral al final del artículo.

Originalidad: La proposición general del ensayo se relaciona con la Legitimidad Política, constituyente del Estado, en sus relaciones con los regímenes y formas de gobierno, y con la confianza atribuida a la acción política, como factor involucrado en la Fragilidad manifestada en los Estados.

Contribuciones teóricas y prácticas: Los temas de la legitimidad política y el Estado presentan prometedoras posibilidades explicativas ante los recientes cambios geopolíticos. La fragilidad de los Estados es un tema abierto y relevante, en el que este artículo contribuye con la interacción de nuevas variables y el apoyo del constructo statehood para sustentar nuevos estudios sobre la fragilidad del Estado.

Palabras Clave: Fragilidade dos Estados, Legitimidade Política, statehood.

\section{INTRODUCTION}

The formative elements of state capacity and stability vary over time, interfering with the conditions of fragility, which may be related to the precariousness of institutions and the inability to meet the wishes of the population. The strength of States has long been considered as an important factor in ensuring, among other things, democratic consolidation (Linz, Linz, \& Stepan, 1996), the rule of law (O'Donnell, 1993), the adequate provision of basic public goods (Rotberg, 2004) and economic growth (Coatsworth \& Taylor, 1998). On the other hand, the fragility of State also has a profound impact on approaches to key issues of global concern, such as climate change, poverty and violent conflict, political instability (Grävingholt, Ziaja, \& Kreibaum, 2012), so that the Fragility of the State can be assumed as an important element that impacts the agenda of international bodies. Giraudy (2012) points out that research on the strength of the state is hindered by its dichotomy, that is, States are placed at two ends: weak or strong. According to this author, 
this is controversial, in view of the fact that States are grouped, and as a result, the label 'Weak States' denotes a variety of empirical cases that, in the main, differ widely.

In agreement with such idea, Bresser-Pereira (2017) points out that, in each country, the State will be more or less strong or capable as the national society is in terms of cohesion, the more breadth it has as a NationState and greater respect for society. For Grävingholt, Ziaja and Kreibaum (2012), the differentiated view of state fragility shifts from a one-dimensional concept to a multidimensional concept. This time, it is important to understand the many facets that lead a country to a fragility condition that may compromise it in different ways. Therefore, the need to understand the Fragility of States, Mazzuca (2012) argues that after the 'double collapse of New York', that of the Twin Towers in 2001 and that of the Lehman Brothers in 2008, the State returned to the forefront of world politics. The attack on the Twin Towers revealed the structural fragility of international security in the face of the resurgence of Islamic terrorism. On the other hand, the bankruptcy of Lehman Brothers was part of the explosion of a financial market bubble in the United States and the European Union, leading to the weakness, fragility or failure of the States to become one of the main political and international relations narratives in the post-Cold War era (Grävingholt et al., 2012).

However, deciphering all these aspects presents itself as a great challenge. For this reason, the most recent contributions have highlighted the importance of disaggregating the Fragility of the State into key dimensions to be considered individually, as well as in their interaction (Grävingholt et al., 2012). Thus, these authors corroborate Call (2011), both in regard to the importance of the distinction and its conclusion that the reality of fragile States differs in quality, depending on which dimensions of the state are extinguished (Grävingholt et al., 2012).

Therefore, the structural characteristics of the States and their permanence in successful conditions or not in relation to fragility can be gauged under the statehood construct. This term considers Authority, Legitimacy and Capacity (ALC) as forming dimensions, which allows even an evolutionary view of such conditions (Tikuisis, Carment, Samy, \& Landry, 2015). Considering the facets of fragility and its consequences from the statehood construct, it is noted that it refers to the strength or weakness associated with the quality of the State per se. In other words, the combination of the variables (ALC) is able to indicate a particular condition of the State, attributing, in this sense, statehood as a condition of the State.

In view of the most diverse crises, conflicts and past problems, the elites of the advanced countries have turned to the State as a source of solutions (Mazzuca, 2012). In this sense, understanding that both capacity and authority are characteristics intrinsic to the State and that these represent the nucleus of governments, as more immediate products of a certain condition of the State, considering the various transitions of States throughout history and geopolitics, in this essay, we seek, in the political legitimacy of government, a more complex and dynamic variable that is defined in different temporal and spatial degrees, with a view from society to the government. In other words, it is not given, it is a consequence of the interpretation of actions from their comparison with socially recognized values.

When speaking about political legitimacy, it is possible to consider both the legitimacy of the State and the legitimacy of the government. While the State enjoys legitimacy when its law is respected and observed, a government has legitimacy when its rulers count on the support of the nation and civil society. In the described scenario, it is understood that legitimacy is a structural characteristic of the States, which can contribute to the successful exit from the fragility condition in some cases, and to the maintenance of status, in other cases.

In this context, the Fragility of States is studied in the view of the possibility of conflicts (Tikuisis et al., 2015; Carment, Samy, \& Prest, 2008; Call, 2011), besides an external aid perspective (Barakat \& Larson, 2014; Nettl, 1968). Adjusted to the construct statehood, the studies converge for the construction and formation of States (Fukuyama, 2005; Baranyi, 2012), and for criterion or dimensions of fragility of the States (Tikuisis et al., 2015; Carment et al., 2008). In this convergence, Carment, Samy and Prest (2008) studied the capacity of states. Colonization was cited as cause by Dewey (2012), Fukuyama (2005) and 
Baranyi (2012); the sovereignty of states and the structure of governments were cited by (Deegan, 1999), and, among others, Mazzuca (2012) questions whether the 'holy trinity' - Authority, Legitimacy and Capacity - are attributes of the State, the regime, or the government.

This essay seeks to align these variables with the political legitimacy construct, assuming that this variable is capable of leading to a link between all conditions or their overruns. Considering statehood as a condition or status of a State, history plays an important role in understanding the mutuality of the State. In other words, it is neither an infinite formation nor a political exercise subject to frequent changes, but legitimacy is. This time, political legitimacy helps to understand how these degrees of state have been socially constructed and challenged over time.

Considering that legitimacy rests on local and extra-local forces, it is socially constructed by local actors in local conditions (Scott, 2000) and depends on regional stability and international support capacity (Tikuisis et al., 2015; Grävingholt et al., 2012; Carment et al., 2008), permeating the sense of State; and such statehood refers to a set of attributes of the States (Baranyi, 2012). Legitimacy will be an ingredient that confers to it the ability of fulfilling the expectations of society, that is, political legitimacy figures as an essential element and interdependent role of government and state. In view of the above, the general proposition of the present essay is related to Political Legitimacy, constituent of Statehood, in its relations with regimes and forms of government, and with the confidence attributed to political actions, as a factor involved in the Fragility manifested in the States. In addition, for researchers, it is important to address these gaps, since the search for a path of State weakness must be informed by means of a rigorous understanding of the different manifestations of the State and its constitution, by different actors over time.

Based on this introduction, this essay is structured as follows: the first topic presents the construction of the State. The second topic addresses the concept and impacts of a fragile State. The next topic is the statehood construct, followed by a discussion about the concepts of Legitimacy as a reflection of political action. The convergence of the three themes, which is the purpose of this essay, is discussed in the topic that seeks the relationship between political legitimacy, statehood and Fragility of States. This topic results in the proposal of a comprehensive model for the Fragility of States.

\section{The Concept and Construction of States}

According to Carneiro (1977), there are two types of theories about the origin of the State, namely, voluntarist and coercive. Voluntarist theories hold that at some point in history, certain peoples spontaneously, rationally and voluntarily gave up their individual sovereignties and joined with other communities to form a larger political unity that deserves to be called the State. Among such theories, the most well-known is the old Theory of the Social Contract, which was especially associated to the name of Rousseau. Regarding the Coercive Theory, Carneiro (1977) emphasizes that deeper historical investigation demonstrates that only a Coercive Theory can explain the rise of the State, the force, rather than the enlightened self-interest, the mechanism by which political evolution changed, step by step, from autonomous villages to the state.

In this sense, Tilly (1996) points out that history corresponds to capital and coercion. States reflect the organization of coercion and present the effects of capital, a combination that produces distinct types of State. War induces the formation and transformation of the State. Extraction and struggle for the means of war have created the central organizational structures of States. Those who have lost wars have commonly contracted, and often ceased to exist Tilly (1996).

In this context, the concept of State is linked to the control methods that a government is able to manage over a given territory, and, throughout history, several characteristics and concepts have been attributed to the States. The concept of 'State' has two meanings: sometimes it means an apparatus related to government or power, and sometimes it is subordinate to that government or power, as a social system. However, this 
ambiguity is not a concern for social theory, and stresses that all States integrate the circumspect monitoring of the reproductive aspects of social systems subject to their dominance (Giddens, 2001).

For Weber (2015), the State differs from organizations by three main elements: i) the existence of both regular and trained administrative support; ii) the maintenance of the legitimate monopoly right to control the means of violence, and iii) the continuity of this monopoly within a specific territorial area. It also defines the State as primarily geared towards the Modern State, where it reaches its full development. In this sense, it is defined by understanding that States can change.

Circumscribed to this scenario, the concept of State exists where there is a political mechanism of government (government institutions) controlling a territory whose authority has a system of laws and the capacity to use force to implement its policies. In this scenario, turning to modern societies, Giddens (2001) draws attention to the interconnected unity, society, understood as the central nucleus of the Nation-State.

According to Malešević (2017), since the end of World War II, the nation state has been gradually institutionalized as the exclusive and legitimate form of territorial domination. This view is defined in the Charter of the United Nations, Article 2 (Chapter 1), reaffirming the notion of "sovereign equality of all its Members" and certifying that no member may use force against territorial integrity or political independence of any Nation-State (Maleševic', 2017, p. 146).

This leads to the discussion of three characteristics that distinguish the Nation-State from other concepts of State: i) Sovereignty, whose principle is the exercise of absolute authority that a government should have over the territory to which it belongs; ii) Citizenship, linked to the right of citizens, that is, those who hold the right to participate in the political life of a State; and iii) Nationalism, as the most characteristic aspect of a Nation-State, a feeling linked to a set of symbols and convictions seen as representative traits of a determined national identity.

According to Berg and Kuusk (2010), sovereignty was identified based on the Peace of Westphalia, an agreement that established an institutional arrangement for political organizations and proceeding of the Modern State. A clear border was established for the State, affirming its authority on its side of the border and incorporating the people who lived there, characterized as citizens. Biersteker and Weber $(1996$, p. 3) refer to sovereignty as "a normative conception linking authority, territory (population, society) and recognition". For Bresser-Pereira (2017), a type of sovereign political-territorial society, located in a territory and formed by a nation, can be defined as a Nation-State. While a State is a political and geopolitical entity, a nation is an ethnic and cultural integration. Thus, 'Nation-State' implies simultaneity.

The construction and evolution of the States are related to the creation of new governing institutions and the strengthening of those already existing. According to Fukuyama (2005), the construction of states has been shown as one of the basic themes for the international community, because fragile, failed or weak States are at the heart of a number of problems, such as poverty, disease, drugs, terrorism and political instability.

\section{Fragility of States}

States considered fragile represent a challenge for policymakers. For Tikuisis et al. (2015), States are expected to thrive and thrive over time, yet many, though credible, are unable to evolve. Others advance only in certain areas. An impact of this situation, according to Tikuisis et al. (2015), is that States considered stagnant are less likely to overcome their political, economic and social unrest. As a consequence, they are considered vulnerable to the fragility traps of external aid.

The earliest papers discussing the bankruptcy/fragility of states mention Somalia (Helman \& Ratner, 1992) as an example of a Nation State that ceased to function as a sub-state entity. In this regard, the expression 'failed states' conceptualizes the development of new armed conflicts and the succession of postCold War problems (Holsti, 1996; Jänicke, 1990; Kaldor, 1999; Yoffee \& Cowgill, 1991). 
In agreement with this rationale, the term 'fragile state' started to be used in the discussions both in the academy and international bodies and in the formulation of public policies. However, the concept was eroded to the extent that different international actors, such as the Organization for Economic Cooperation and Development (OECD), World Bank, United States Development Agency (USAID) and United Kingdom Department for International Development (DFID), among others, highlighted different aspects of fragility in their normative documents.

Therefore, categories that could represent the weakness of the State, considered a prediction of state bankruptcy, were propagated. Thus, while the terms 'Failed State' and 'Collapse State' are usually allocated to situations in which the government and its institutions have ceased to function or even exist, 'Fragile State' and 'Weak State' have been adopted to describe countries that have not met Weberian State expectations, including functionality, and are in danger of collapsing in the future. For Rotberg (2004), 'weak States' can be divided into two basic categories, although some combine characteristics of both: (a) States inherently weak because of geographical, physical or economic constraints; (b) basically strong but temporarily in a condition of weakness due to internal antagonisms, management failures, greed, despotism or internal attacks.

Understanding the fragility of a country involves assimilating the inconsistency of organizational structures, combined with the inability to satisfy the desires of society, this implies an image of uncertainty as to stability or security, or due to the occurrence of political disturbances, which lead to massive displacements of refugees, and may precipitate conflicts caused by the proliferation of criminal and extremist groups in their territories. Still, according to Rotberg (2004), it is possible to define the fragility of the State from the understanding that material conditions limit the quality and scope of State actions. In this context, it is feasible to assess the fragility of States based on criteria such as inability to control fractions of their territory, inefficient social and economic performance, inflation, corruption, urban violence, poor infrastructure and poor quality of public services, such as health and education systems, limitations on political freedom and participation.

The corollary for a fragile State is the view that certain countries do not have the material conditions that would shape them as a factual State, due to anarchy or chaos, whether political, social or economic. It must be pointed out that, in this case, the view of anarchy is eloquent because it reflects the apprehension that the phenomenon of failure and (or) state fragility is distinct from other political phenomena, such as revolutions or civil wars. That is, it is understood as apolitical, since it conceives that the political process itself, associated with the idea of the State, has collapsed.

Fukuyama (2005) points to the existence of a hierarchy between the functions of the State, so that the defense from possible external invasions, public security and order are necessary conditions for the State before other forms of return of their functions to society are accomplished, such as universal health insurance or free college education. The strength of the state, defined as the institutional capacity to "plan and execute policies and enforce laws in a clean and transparent way"; Fukuyama (2005, p. 23) lies in its ability to fulfill the most in the hierarchy. This relation is called by the author as the 'scope' of the State.

Thus, Tikuisis et al. (2015) address the fragility of states and recognize that they become fragile and fail for reasons that may be both qualitatively and quantitatively different, given the unique problem settings that often require different policy responses. Studies focused on the persistence of fragility are based on limited interpretations of the development of the State equivalent to economic growth (Andrimihaja et al., 2011). Pritchett et al. (2013) argue that this persistence is based on the types of aid entrusted to fragile states and on the subsequent lack of an optimal response, which undermines the development of strong institutions and public administration strategies.

Finally, the concept and studies on the fragility of States are not only a new concern of the international community with the potential repercussions of the inability of some States, but also, and above all, with the fact that this condition can lead to a growing loss of internal legitimacy and in more serious cases, collapse, as pointed out by Rotberg (2004). A 'failed State' is estimated as a means of regional destabilization, serving 
as a refuge for extremist and criminal groups, generating massive refugee outflows and a scenario of disputes among other States interested in expanding their area of influence.

The discussion from the Fragility of the State leads to the following proposition:

The combination of material and institutional conditions and expectations of society defines the consistency of States in their commitment to overcoming Fragility conditions.

\section{The Statehood Construction and its Relationship with the Fragility of States}

According to Carvalho (2007), a State will be so much stronger as its complexity is inherent to the formulation of public policies and the capacity of its apparatus to realize them. Thus, it is the completeness between an effective scope of activities and an efficient State capacity that can provide an analytical framework for the evaluation of State performance.

In this context, statehood can be defined as a set of properties that States manifest, with varying degrees over time (history), space (territorial scope) and domain of activity (scope). Its main attributes are the administrative capacity to provide essential public services (such as security, governance, health, education, social assistance and basic infrastructure) and to increase the revenues of these public goods (Baranyi, 2012). According to the US Agency for International Development (USAID, 2005), the instability associated with Fragile States is a product of ineffective and illegitimate governance. In addition, the Fragility of States is supported by four essential pillars of stability: security, economic conditions, policies and social welfare. For the agency, the fragility of the State is a consequence of the State's failure to provide basic services, either completely or to a certain extent, and its inability to provide domestic security and maintain the integrity of its borders. For Malešević (2017), it is categorical the difficulty of measuring the Fragility of the States and its reflection in the studies on statehood.

The fragmented analysis of State fragility can use a parsimonious model, based on the idea that a State must exhibit three fundamental properties: Authority, Legitimacy and Capacity (ALC), and that weaknesses in one or more of these dimensions will have an impact on the general fragility of a given country (Tikuisis $e t$ al., 2015). In this respect, any State may be moderately strong in certain dimensions of statehood, despite being weak in others. The combination of the results of these categories (ALC) may indicate a functionally strong or structurally fragile State. High capacity, for example, is not enough for a strong state if legitimacy is low, and the same is considered for the three categories of ALC (Tikuisis et al., 2015).

Carment $e t$ al. (2008) point out that the unprotected state of authority may not be able to control the full extent of its legal territory. In this context, these States are likely to have difficulties in responding effectively to internal or external threats (Weber, 2015). In this sense, the author distinguishes, at first, power as the ability to influence or even induce the behavior of other people, whereas domination, or authority, is presented as the acquired right to be obeyed, which allows its influence within a group. In this regard, Weber (2015) describes three types of authority: Rational Legal, Traditional and Charismatic, mainly depending on the bases of the society in question, that is, depending on the measure of legitimacy.

According to Tikuisis et al. (2015) and Grävingholt et al. (2012), when the authority of a State is reduced, the State's ability to protect its citizens against intentional violence is also diminished, since the State is fragile in defining and executing its rules. In this scenario, "by implication, authority is thus related to the degree to which the state can guarantee the physical integrity of its citizens and protect them from physical threats", (Carment et al., 2008, p. 352). They further complement that, since authority is a precept of the State's ability to project force, security becomes a basic premise for the realization of public affairs, public and private interests and civil society.

Capacity is linked to the precept of the State institution inability to provide a minimum of public policies and services to the population. Capacity, paradoxically, refers to both the scope, as the role of functions that the state must, and strength, as the ability to fulfill services entrusted to it by the population. In terms of 
scope, most analysts tend to agree with a set of primordial State functions, equivalent to those identified in the 1997 World Development Report, as minimum functions of defense, public order, health, macroeconomic management and disaster assistance (Fukuyama, 2005).

Call (2011) explains the capacity of the State as the extent to which State institutions are able to provide or regulate the minimum provision of essential public goods, hence the functions of security, rule of law, public finance management and property, such as education and primary health care. For the author, however, the capacity of the State does not exclude private or non-State actors from providing services, under State regulation. Moreover, it does not include the degree that the State contemplates good governance, holds democratic policies or economic prescriptions (Call, 2011).

Lastly, Carment et al. (2008) point out that States with satisfactory level of capacity demonstrate competence in political and economic management and administration. Their governments are able to regulate internal services and carry out international transactions. The authors add that these States must also support the basic infrastructure necessary for a modern State, including functional transport. Thus, those States without capacity tend to be subject to civil society and the international community with regard to the provision of vital public goods and services that may prove incapable of effectively addressing unexpected shocks, such as epidemics, disasters, food shortages or refugee flows.

In addressing the weakness of the State, Fukuyama (2005) seeks to break the 'conceptual confusion' about the characteristics that describe political unity, what is conceived as statehood. The author argues that statehood is divided into two dimensions: first, the scope of state activities, and second, State power. The latter, on the other hand, disregards the government lack of clear understanding of the difference between these two functions. One of the confused ideas about statehood is that the word force, is often used for what is called both as scope and force or capacity (Fukuyama, 2005). It should be emphasized that he does not rule out that a strong state can also fulfill with great strength or capacity the functions considered 'intermediary' or 'activists'; however, the fulfillment of these functions is only a complement to the basic functions, whose good performance primarily characterizes a strong State.

This multidimensionality of statehood follows the condition of combined qualities of state, introduced by Nettl (1968) as a continuous variable, which could be disaggregated into its constituent elements. Facing the discussion between the constructs of statehood and State fragility, the following proposition is considered:

The ability to overcome Fragility conditions manifests itself in governance, institutional structures and state power of action.

Therefore, for this work, Baranyi (2012) is followed by pointing out the most important characteristics of statehood in the eyes of its citizens.

\section{Legitimacy and Political Action}

Political legitimacy is defined here on the basis of Beetham (1991), which considers the consensus, both behavioral and normative, to determine the meaning of legitimate power. The definition of Beetham (1991) includes three essential components: (i) the conduct of a State, or legality, which concerns the State compliance with its own laws, (ii) shared norms, or justification, which ensures that (iii) express acceptance, or consent, which demonstrates the recognition of citizens in the legitimate domain of a State (Beetham, 1991; Gilley, 2009).

Pfetsch (1998) points out that the political legitimacy of the state is directly related to the capacity to act, evidenced by the success achieved, which results in legitimacy. "A political system is accepted not only by the granting of rights and guarantees or by participation, but also by a successful policy" (Pfetsch, 1998, p. 104).

Easton (1965) argues that a government legitimacy comes from the attitudes of citizens, who by implication can individually grant more or less support in each dimension. Different countries would have varying degrees of legitimacy, based on the average positions of their citizens. In this sense, three 
objects of such support are distinguished: the community, the regime (that is, prevailing ideological values, constitutional rules and authorized structures of the political game) and the authorities (the government of the day and other occupants of the roles of formal political authority).

According to Lipset (1959), the ability of the system to produce and maintain the belief in political institutions is the most admirable part of a society. In this context, Dogan (1992) questions whether the legitimacy of a political system can be judged in terms of the subjectivity of people adherence. It is assumed that trust is a subjective phenomenon, even when analyzed objectively. Lipset (1959, p. 378) point out that "people lose faith in leaders more easily than they lose confidence in the system".

This approach is congruent with the thinking of Weber (2015), by pointing out that no domination is voluntarily satisfied with merely material or affective or rational motives concerning values, as probabilities of its persistence. All seek to awaken and cultivate beliefs in their legitimacy, which depends on the nature of the legitimacy desired. The type of obedience and the administrative framework proposed to guarantee it differ, as well as the character of the exercise of domination, as claimed by Dogan (1992), who points out that the idea of legitimacy, once obtained, can be preserved. Thus, political legitimacy refers to the ability of a State to conduct public loyalty and generate internal support for government legislation and policies. Weber (2015, p. 139) describes that "every action and, in turn, particularly social relations, can be oriented on the side of the participants, by the representation of the existence of a legitimate order". Such support must be coined through a voluntary and reciprocal convention of effective governance and citizenship, refined in widely accepted principles of selection and succession of governments recognized both locally and internationally.

The support that citizens give to any government depends, to a large extent, on the level of political legitimacy of the government. Avery (1988, p. 112) rescues Weber in arguing that legitimacy involves: "The degree to which institutions are valued for themselves and considered correct and adequate", in this context, Avery (1988) still retakes Merelman (1958), who noted that political legitimacy is the quality of 'duty' perceived by the mass public as inherent in a political system, i.e. for these authors, a legitimate government is intuited as morally appropriate for a society. There is a consonance among the governed that authority is properly distributed and exercised, that is, achieved when political institutions and procedures are seen as reflecting the basic values of individual citizens. Government actions, therefore, carry the strength of moral sanction and the level of public compliance is often high.

Dogan (1992) relates the concepts of legitimacy and effectiveness to understand that this link is essential in the political system. This can be explained by the fact that the presence or absence of one, over time, may imply the loss or increase of the other. Lipset (1959) describes that this relationship probably maintains the stability of the political system and also considers that effectiveness is tied to the government performance in extending and satisfying the basic functions of society. For the author, when confronted with crises of effectiveness, such as an economic crisis, the stability of the regime depends, to a large extent, on the degree of political legitimacy.

In this context, Claude (1966) argues that legitimacy must prove to be an important factor in politics, which in turn, must be beyond power struggle. This view corroborates Grävingholt et al. (2012), considering the broad consensus existing throughout the literature that fragile States take very different forms. In this sense, some fail to provide basic services and face the erosion of authority as a consequence. Others are drowning in civil wars or criminal violence. And yet, others are unable to extend their reach in all parts of their territory, where populations of certain areas do not recognize the legitimacy of the central State authorities (Grävingholt et al., 2012).

In some cases, these different types of problems combine and exacerbate each other. According to Hertz (1978, p. 320) cited by Dogan (1992), legitimacy has different degrees, from levels of complete compliance to rejection. Support, consent, conformity by decline, erosion and loss are aspects that can lead to these levels, while illegitimacy occurs in cases of conscious rejection. Finding an answer to these degrees, or a gap of legitimacy, is a complex path. Cordeiro (2005) states that the 'legitimacy gap' refers to the degree of popular 
consent and acceptance of the national governance system. In some cases, low legitimacy reflects low capacity. A new government that is unable to provide minimal services in the immediate term may see a decline not only in its popularity but in support of the general regime. Here, capacity and legitimacy reinforce each other (Call, 2011). This author agrees with Carment et al. (2008), arguing that there is a legitimacy gap in a State where a significant portion of its political elites and society rejects the rules governing the exercise of power and the accumulation and distribution of wealth. According to Rothschild (1977), it is clear, both in literature and in society, that there are several concepts of legitimacy, but the principle of political legitimacy of government vis-à-vis the State mainly depends on the population perception of the political system as a whole, and of society trust in it. Although different principles of political legitimacy and agents of legitimacy can be simultaneously operative within a given political unit and among the conscious units of the global political system, there is nevertheless a tendency for a single concept of political legitimacy to become generally dominant in a particular way to obtain broad acceptance as the decisive standard. Indeed, the existence of such a consensus can be seen as the essential feature of a cohesive and stable political system at both national and international levels (Claude, 1966).

Thus, regarding the political legitimacy of the government vis-à-vis the State, the following proposition has been offered:

Governance and trust of society before its government in weak States is an element capable of leading to its political legitimacy, strengthening its institutions and supporting the country in crisis situations.

\section{The Search for Relationships between Political Legitimacy, Statehood and Fragility of States}

As already mentioned, State Fragility must be considered as an important issue that impacts the agenda of international bodies. For Grävingholt et al. (2012), the differentiated view of State Fragility shifts from a onedimensional concept to a multidimensional concept. That is, it is necessary to understand the many facets that lead a country into a fragility condition that may compromise it in different ways.

The formally declared and generally recognized desire for political legitimacy addresses the status of a constant characteristic of political life. This desire demands that power be converted into authority, jurisdiction be supported by jurisdiction, and ownership be validated as property. For Avery (1988), legitimate authority must be distinguished from power, since a political regime may have power, but lack proper authority. Avery (1988) further recognizes, according to the definition of Thomas Hobbes, that authority can be understood as the right to do. When authority is absent, power in form is usually present. For this reason, the State is often recognized as the owner of the monopoly on the means of force in society (Avery, 1988).

Political legitimacy is a structural characteristic of States. Therefore, the competencies and legitimacy of government and State are directly related to the capacity to act, which is evidenced by the success achieved, with consequent legitimation, so that the acceptance of a political system is not only granted by rights and guarantees or participation, but also by a successful policy (Pfetsch, 1998).

According to Dogan (1992), tensions over legitimacy and loss of confidence can be explained in part by the difficulty in guiding society. There are two opposing types of ungovernability: when the government is overwhelmed by the demands of a very complex society and is doing too much, as in advanced democracies called welfare states; or it is not doing enough because the State is economically weak and lacks the necessary resources to affect society. In this sense, even Dogan (1992) points out that, in advanced democracies, the loss of confidence in institutions or rulers and consequent political criticism come from the fact that rulers must make decisions under direct and permanent scrutiny of the public. In a legitimate regime, people have the right to criticize. 
In this sense, Dogan (1992) points out that it is not appropriate to assume that, in a given country, legitimacy exists only because it is not disputed. States where the regime of government does not have broad and voluntary domestic support or generalized international recognition allow for a lack of legitimacy. Such States face significant difficulties in maintaining relations among the various communities within the state, and any security encountered within the state is possibly a consequence of the opposing coercion of popular consent. As a result, such States are inherently vulnerable to internal disruption, and possibly remain fragile as long as political legitimacy continues to be lacking (Carment et al., 2008).

Call (2011) shares the view of Carment et al. (2008), who claim that there is a legitimacy gap in a State where a significant portion of its political elites and society rejects the rules governing the exercise of power and the accumulation and distribution of wealth. Although a State may also experience a lack of external legitimacy, other States do not recognize or accept its borders or its internal regime.

In view of the discussion, the following proposition is presented:

The loss or variation of governmental legitimacy, which may occur through the omission of the State, may be the cause or effect of the fragility condition of the country vis-à-vis the international community.

\subsection{Comprehensive Model for Fragility of States}

According to Mazzuca (2012), the State is considered as an accumulation of resources; the government, as a group of actors; the regime, as a set of rules; and the administration, as a mix of rules and actors, while actors are characterized by Giddens (2001) as society as the central nucleus of the Nation-State. Rotberg (2004) points out that States are marked by insufficient basic political goods, including human security and State security, the resolution of differences and regulation of norms, essential political freedoms and economic opportunities for the majority, otherwise the entire population would not recognize the legitimacy of the government, which would result in the Fragility of the State.

This time, since the political legitimacy of the government is not an inherent attribute of the State, political legitimacy is defined as the belief that obedience to the order of the State is justified, which Dogan (1992) considers as confidence. However, autonomy and capacity refer to inherent attributes of the state; on the one hand, its objectives - what Mazzuca (2012), Carment et al. (2008) and Tikuisis et al. (2015) call the agenda or its preferences, and, on the other hand, the resources available to reach them (Mazzuca, 2012; Carment et al., 2008; Tikuisis et al., 2015).

In the relationship between State and government, the regime and forms of government are important variables, since they can affect both the legitimacy and the trust of society. Since trust depends on the performance of the government, this relationship is mediated by society, thus guiding the actions of the government and those who can confer political legitimacy to the government and the State. Therefore, the statehood, associated with the quality of the State per se, permeates the State, the government and society. Fragility shows itself as a consequence of the relations between all the variables of the model.

Finally, the concept and studies on Fragility of States do not mean only a new concern of the international community with the potential repercussions of the inability of some States, but also, and above all, that this condition may lead to an increasing loss of internal legitimacy and cause a collapse, as pointed out by Rotberg (2004). A "failed State" is estimated as a means of regional destabilization, serving as a refuge for extremist and criminal groups, generating massive refugee outflows and becoming the scenario of disputes among other states interested in expanding their area of influence. 


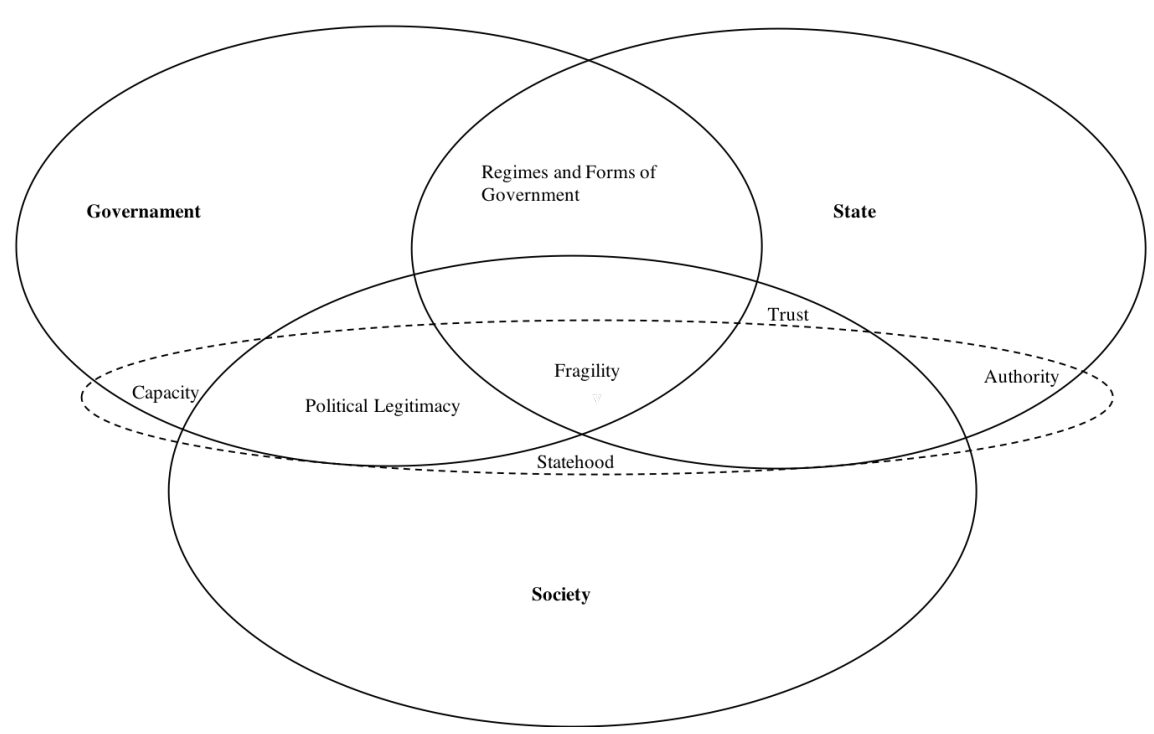

Figure 1: Proposal for a Comprehensive Model

The discussion and model presented give rise to the following general presupposition for this study:

Political Legitimacy, constituent of Statehood, in its relations with regimes and forms of government, and with the confidence attributed to political actions, is an intervening factor in the manifest Fragility in the States.

\section{Final Consideration}

From the period before and immediately after World War II, the condition of the States was focused by the academic literature. Recently, although declining, the international community has reduced its border requirements and the definitions of the constituents of the viability, fragility and bankruptcy of States.

As already pointed out, studies focused on the persistence of fragility are based on interpretations that treat development as economic growth, while the literature itself argues that this persistence is based on the types of aid entrusted to fragile states and on the subsequent lack of an optimal response, which undermines the development of strong institutions and public administration strategies. However, this process analyzes not only a history of economic growth or stagnation.

Neither is it something that is defined solely within a system of power relations. It is in this context that this essay was inserted and raised the assumption that the consequence of the government legitimacy loss becomes a relevant dimension for governability itself and the benefit of society.

Due to the consequences of political legitimacy, it is perceived as dependent, regulated and interceded by legitimacy. It is possible to change the acceptance of society, as well as its ways of acting, its capacity to raise resources in the environment, its results and survival. Depending on historical circumstances, maintaining political legitimacy, as well as its denial, may virtually characterize any form of political condition and stability of institutions, regardless of the presence of crises.

In fact, even when society accepts actions taken by the government against its interests, and even if it is a traditional, though totally legitimate, system, the government is subject to erosion and delegitimation in the long run if it becomes chronically incompetent or ineffective.

In the relationship between political legitimacy and statehood, State Fragility is challenging, precisely because the government must have sufficient initial legitimacy to achieve the production efficiency needed for its further legitimation. However, it is possible to affirm that the legitimacy achieved or lost by the rulers before their society can be one of the fundamental aspects of leaving or staying in a State fragility. 
The topic of political legitimacy and statehood also presents promising explanatory possibilities in the face of the geopolitical changes in recent decades. These changes are due to reconfigurations and the emergence of new sources of power at the international level, parallel to new developments in technology, communications, production, consumption, etc. In this respect, the fragility of States is an open and relevant topic.

\section{REFERENCES}

Avery, W. P. (1988). Political legitimacy and crisis in poland. Political Science Quarterly, 103(1), pp. 111-130.

Barakat, S., \& Larson, A. (2014). Fragile states: A donor-serving concept? issues with interpre-tations of fragile statehood in afghanistan. Journal of Intervention and Statebuilding, 8(1), 21-41.

Baranyi, S. (2012). Contested statehood and state-building in haiti. Revista de Ciencia Política, 32(3).

Beetham, D. (1991). The legitimation of power. Palgrave Macmillan.

Berg, E. \& Kuusk, E. (2010). What makes sovereignty a relative concept? empirical approaches to international society. Political Geography, 29(1), 40-49.

Biersteker, T. J., \& Weber, C. (1996). State sovereignty as social construct. Volume 46.

Bresser-Pereira, L. C. (2017). Estado, estado-nação e formas de intermediação politica. Lua Nova, (100), 155-187.

Call, C. T. (2011). Beyond the 'failed state': Toward conceptual alternatives. European Journal of International Relations, 17(2), 303-326. Cambridge University Press.

Carment, D., Samy, Y., \& Prest, S. (2008). State fragility and implications for aid allocation: An empirical analysis. Conflict Management and Peace Science, 25(4), pp. 349-373.

Carneiro, R. L. (1977). A Theory of the Origin of the State. Studies in Social Theory No. 3, 169(3947), 3-21.

Claude, I. L. (1988). Collective legitimization as a political function of the United Nations. In States and the Global System, 145-159. Palgrave Macmillan, London.

Coatsworth, J. H., Taylor, A. M., et al. (1998). Latin America and the world economy since 1800. Harvard University Press Cambridge and London.

Deegan, H. (1999). Structures of government in the islamic republic of sudan: the question of legitimacy and the 1998 draft constitution. The Journal of North African Studies, 4(1), 87-101.

Dewey, M. (2012). The making of hybrid stateness: Sources of police performance in the conurbano. Revista de Ciencia Politica, 32(3).

Dogan, M. (1992). Conceptions of legitimacy.pdf. In Hawkesworth, M. K. M., editor, Encyclo- pedia of Governement and Politics, chapter 7, page 116. Routledge, Taylor e Francis Group, Londres, i edition.

Easton, D. (1965). A systems analysis of political life. New York: Wiley.

Fukuyama, F. (2014). State-building: governance and world order in the 21st century. Cornell University Press.

Giddens, A. (2001). Estado-nação ea Violência: segundo volume de uma crítica contemporânea ao materialismo histórico. Edusp.

Gilley, B. (2009). The right to rule: how states win and lose legitimacy. Columbia University Press.

Giraudy, A. (2019). Conceptualizing state strength: Moving beyond strong and weak states. Revista de Ciencia Política, 32(3), 599-611.

Grävingholt, J., Ziaja, S., \& Kreibaum, M. (2012). State fragility: towards a multi-dimensional empirical typology. IN: Fragility, Aid, and State-building (ThirdWorlds) (p. v). Rachel M. Gisselquist. Taylor and Francis. Edição do Kindle. Taylor and Francis. Edição do Kindle. Routledge.

Helman, G. B., \& Ratner, S. R. (1992). Saving failed states. Foreign policy, (89), 3-20.

Holsti, K. J. (1996). The state, war, and the state of war. Number 51. Cambridge University

Jänicke, M. (1990). State failure: the impotence of politics in industrial society. Penn State Press. 
Kaldor, M. (1999). Old and new wars: organized violence in a global era. Stanford, CA: Stanford University.

Linz, J. J., Linz, J. J., \& Stepan, A., et al. (1996). Problems of democratic transition and consolidation: Southern Europe, South America, and post-communist Europe. JHU Press.

Lipset, S. M. (1959). Some social requisites of democracy: Economic development and political legitimacy. American political science review, 53(1), pp. 69-105.

Maleševic', S. (2017). The foundations of statehood: Empires and Nation-States in the longue duree. Thesis Eleven, 139(1), pp. 145-161.

Mazzuca, S. L. (2012). Legitimidad, autonomia y capacidad: Conceptualizando (una vez más) los poderes del estado. Revista de Ciência Política (Santiago), 32(3), 545-560.

Nettl, J. P. (1968). The state as a conceptual variable. World politics, 20(4), 559-592.

O'Donnell, G. (1993). On the state, democratization and some conceptual problems: A latin amer-ican view with glances at some postcommunist countries. World Development, 21(8), (pp. 1355- 1369).

Pfetsch, F. R. (1998). Capacidade de atuar e legitimação do estado democrático de direito na era da globalização. Revista Brasileira de Política Internacional, 41(2), pp. 102-117. Press. Profile Books. Revista de Ciência Política, 32(3).

Rotberg, R. I. (2004). When states fail: causes and consequences. Princeton University Press.

Rothschild, J. (1977). Observations on political legitimacy in contemporary europe. Political Science Quarterly, 92(3), 487-501.

Scott, W. R. (2000). Institutional change and healthcare organizations: From profes-sional dominance to managed care. University of Chicago Press.

Tikuisis, P., Carment, D., Samy, Y., \& Landry, J. (2015). Typology of state types: Persistence and transition. International Interactions, 41(3), 565-582.

Tilly, C. (1996). Coerção, capital e Estados europeus 1990-1992. Edusp.

United States Development Agency (2005). Fragile States Strategy. (January):1-28. University of Arizona Press.

Weber, M. (2015). Economia e sociedade: fundamentos da sociologia compreensiva. Tradução de Regis Barbosa e Karen Elsabe Barbosa. Brasilia: Editora da UnB,(1921)/1991.

Yoffee, N., \& Cowgill, G. L. (Eds.). (1991). The collapse of ancient states and civilizations. University of Arizona Press. 